\title{
FRESH WATER INFLUENCE ON NUTRIENT STOICHIOMETRY IN A TROPICAL ESTUARY, SOUTHWEST COAST OF INDIA
}

\author{
G.D. MARTIN ${ }^{1}$ - J.G. VIJAY ${ }^{1}-$ C.M. LALURAJ ${ }^{2}-$ N.V. MADHU ${ }^{1}-$ T. JOSEPH ${ }^{1}-$ M. NAIR $^{1}-$ \\ G.V.M. GUPTA ${ }^{3}-$ K.K. BALACHANDRAN ${ }^{1} *$ \\ ${ }^{I}$ National Institute of Oceanography, Regional Centre, P.B.No.1913, Kochi 682 018, India. \\ ${ }^{2}$ National Centre for Antarctic and Ocean Research, Goa, India \\ ${ }^{3}$ Integrated Coastal and Marine Area Management-Project Directorate, Ministry of Earth \\ Sciences, Chennai, India \\ (phone: +91-484-2390814; fax: +91-484-2390618) \\ e-mail*: kkbala@niokochi.org \\ (Received 22 $2^{\text {th }}$ October 2006; accepted $13^{\text {th }}$ September 2007)
}

\begin{abstract}
Cochin backwaters, a micro tidal estuary, undergo a characteristic transformation from a riverdominated system during summer monsoon to a tide-dominant system during pre-monsoon season. The present study observes that as the river flow weakens after monsoon, the flushing of the estuary diminishes and the nitrogen and phosphorous loadings through anthropogenic activities (industries) and sediment re-suspension alter the nutrient stoichiometry substantially. The increased tidal activity during pre-monsoon changes the estuary into a vertically mixed, eutrophic and flow-restricted system supporting an enhanced organic production. This implies that monsoon-induced hydrology plays an important role in regulating the nutrients, secondary production and even the migrant fauna of the estuary. The system is delicately poised, as continuous release of pollutants including nutrients into this estuary would suppress fish and shell fish production, where only pollution tolerant species can exist.
\end{abstract}

Keywords: nutrient stoichiometry, Cochin backwaters, Southwest coast of India

\section{Introduction}

Dissolved nutrients are the raw material for the marine trophic chain and estuaries are the main entry for nutrients coming from continental drainage to the marine environment $[1,5]$. The nutrient supply is greater in estuaries that are near densely populated regions, due to the entry of domestic and industrial waste, urban drainage, and agricultural effluents. The increase of nutrient concentrations in estuarine and coastal waters causes several environmental modifications, such as increases in productivity and fishing yields $[6,8,9,10]$. However, anthropogenic inputs frequently cause excessive eutrophication in the environment, especially where the circulation is restricted, such as in estuaries and coastal regions. Several alterations in chemical characteristics and water quality in such water bodies occur as a result of varying river flows. Such alterations can lead to various ecological consequences like changes in species composition, blooms of phytoplankton and decrease of oxygen concentrations.

Cochin backwaters, one of the largest tropical estuaries of India $\left(256 \mathrm{~km}^{2}\right)$, are facing gross pollution problems following the release of untreated effluents from industries $\left(0.104 \times 10^{6} \mathrm{~m}^{3} \mathrm{~d}^{-1}\right)$ and domestic sectors $\left(0.26 \times 10^{3} \mathrm{~m}^{3} \mathrm{~d}^{-1}\right)$ [12]. Reclamations over the past several decades have resulted in considerable shrinkage of the Cochin backwaters [13]. The hydraulic barriers constructed to prevent saline incursion into the upstream agricultural fields imposed flow-restrictions and increased sedimentation in the estuary $[2,6,14]$. The monsoon-derived alluvium accumulates in the estuary during postmonsoon, whereas silting environment prevails during the pre-monsoon $[15,16]$. The 
natural and anthropogenic factors influencing the geochemistry of sediments in the Cochin backwaters and the adjacent coast have been reported [2, 17]. Many studies have assessed the environmental changes caused by anthropogenic input of nutrients and other materials in this estuarine system, albeit, systematic study over a region covering tidal cycles are not yet reported.

The present study explains the variability in the nutrient distribution and stoichiometry in the lower reaches of Cochin backwaters, as observed during two contrasting seasons. The observations are mainly based on two time-series measurements conducted along 5 locations in the northern limb of the estuary during October 2003 (high river flow) and March 2004 (low river flow).

\section{Materials and methods}

The observations were carried out as a part of the programme "Ecosystem Modelling of Cochin backwaters". The northern limb of the Cochin backwaters was selected as the study area because of its increased anthropogenic disturbance [2, 8, 18,]. Five stations in an approximately $5 \mathrm{~km}$ stretch were occupied for simultaneous time-series measurements during October 2003 and March 2004. Station 1 was situated closer to the inlet and station 5 towards the north estuary in the River Periyar (Figure 1).

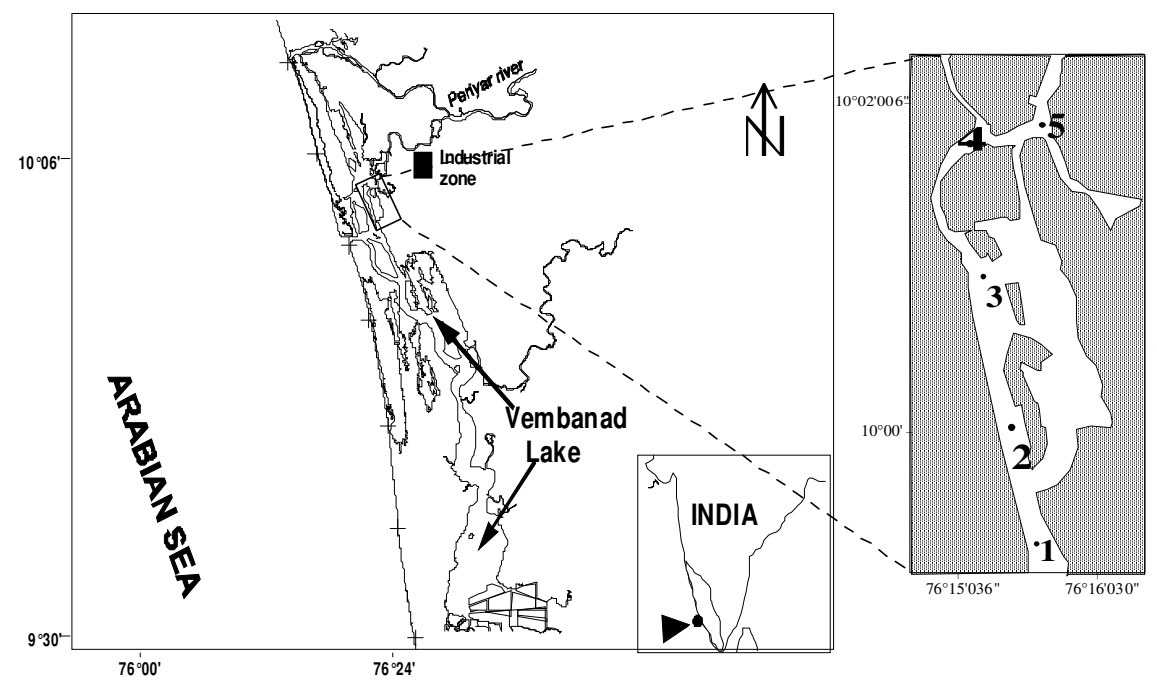

Figure 1. Study area in the Cochin backwaters showing the station locations for the time-series observation.

Variation in water levels, flow, salinity and temperature were recorded from all these five locations at every 10 minutes interval using tide gauges (Valeport) and current meters (RCM9) moored for 30 days continuously during both occasions. Details regarding the sampling and hydrodynamic model development are discussed early [19]. Water samples were collected from $0.5 \mathrm{~m}$ below the surface and from $2 \mathrm{~m}$ depth of these stations at 3 hourly intervals for 30 -h period on 4 occasions, each during October 2003 and March 2004. The samples were subjected to various physico-chemical analyses within an hour of collection (This was possible because the study region was very close to our laboratory). Salinity was determined using a Digi Auto Salinometer (model TSK, accuracy \pm 0.001 ) and the $\mathrm{pH}$ using an ELICO LI610 pH meter (accuracy 
\pm 0.01). Samples for dissolved oxygen were fixed on board and later, estimated following Winkler method [4]. Samples for nutrient analysis (nitrate, nitrite, ammonia, silicate and phosphate) were filtered and analysed in a UV-VIS Spectrophotometer (1650 Shimadzsu) following standard procedure [4]. $250 \mathrm{ml}$ of water sample was filtered through GF/F filter paper, extracted with $90 \%$ acetone for $24 \mathrm{hr}$, centrifuged and analyzed for chlorophyll $a$ by measuring the extinction at 630, 645, 665 and $750 \mathrm{~nm}$ against a reference blank using a spectrophotometer [11].

\section{Results}

\section{Climatic conditions and hydrography}

In order to explain the hydrography and nutrient distribution of the region, we consider a set of observations made during two contrasting seasons. October 2003 was generally a rainy season and $\left(28^{\text {th }}\right.$ October was cloudy with cold winds of speed $\left.4 \mathrm{~m} / \mathrm{s}\right)$. The water column was comparatively turbid, as the secchi depth was $<0.7 \mathrm{~m}$ due the high influx of river-born suspended sediments. In contrast, 22 ${ }^{\text {nd }}$ March 2004 was a sunny and warm day with weak winds and as a consequence, the water transparency increased to $1 \mathrm{~m}$. The variations in the different environmental parameters at surface and bottom of the study region during both seasons are furnished as contour diagrams (Fig.2-5). The presentations of figures are in such a way that the $\mathrm{x}$-axis represents the station locations (approximately $1 \mathrm{~km}$ apart) and the y-axis represents the time of collection, which always starts at 6:00 hrs on each day. Even though station 5 was situated in an adjacent channel, we have considered it to be approximately $1 \mathrm{~km}$ north of station 4, as the tide at this point was found to lag behind station 4 [19]. The dominant fresh water flow on $28^{\text {th }}$ October was indicated by the near zero salinity towards the seaward end of the study area, which however showed saline incursion (618) at bottom during high tide (Figure 2). During pre monsoon (March 2004), increased tidal activity brought in a vertical mixing, as the salinity increased (18-30) in the study region and water was warmer by $4^{\circ} \mathrm{C}\left(28^{\circ}\right.$ to $\left.32.2^{\circ} \mathrm{C}\right)$ as compared to the previous season (Figure 3). The salinity variation generally shows that the region experiences semi-diurnal mixed tides, which was more intense during March, as observed early [10]. The river discharged lowered the $\mathrm{pH}$ below 6 in October, but the pre monsoon season indicated a recovery, when the $\mathrm{pH}$ increased considerably (7.4 to 8).
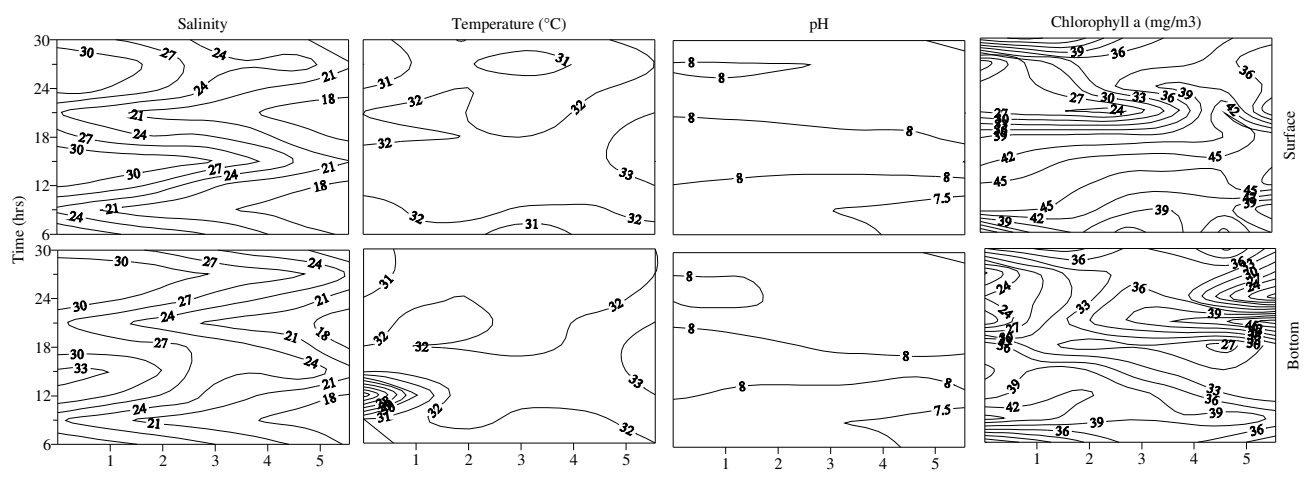

Figure 2. Time-series variation in salinity, temperature $\left({ }^{\circ} \mathrm{C}\right), \mathrm{pH}$ and chlorophyll $\left(\mathrm{mg} / \mathrm{m}^{3}\right)$ at surface and bottom waters on $22^{\text {nd }}$ March 2004. 

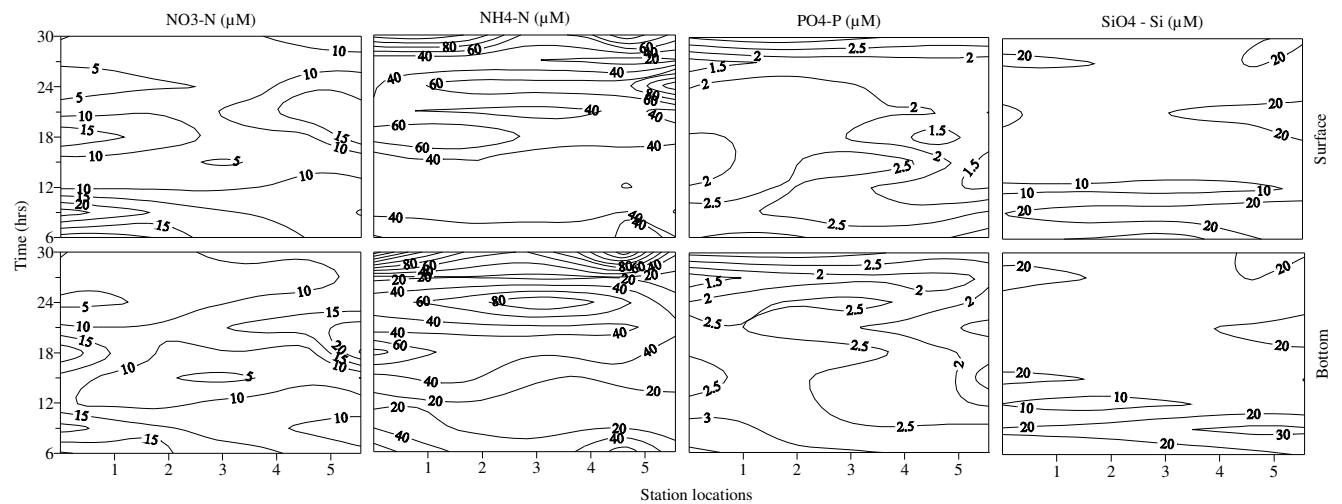

Figure 3. Time-series variations in nitrate $(\mu M)$, ammonia $(\mu M)$, phosphate $(\mu M)$ and silicate $(\mu M)$ at surface and bottom waters on $22^{\text {nd }}$ March 2004.
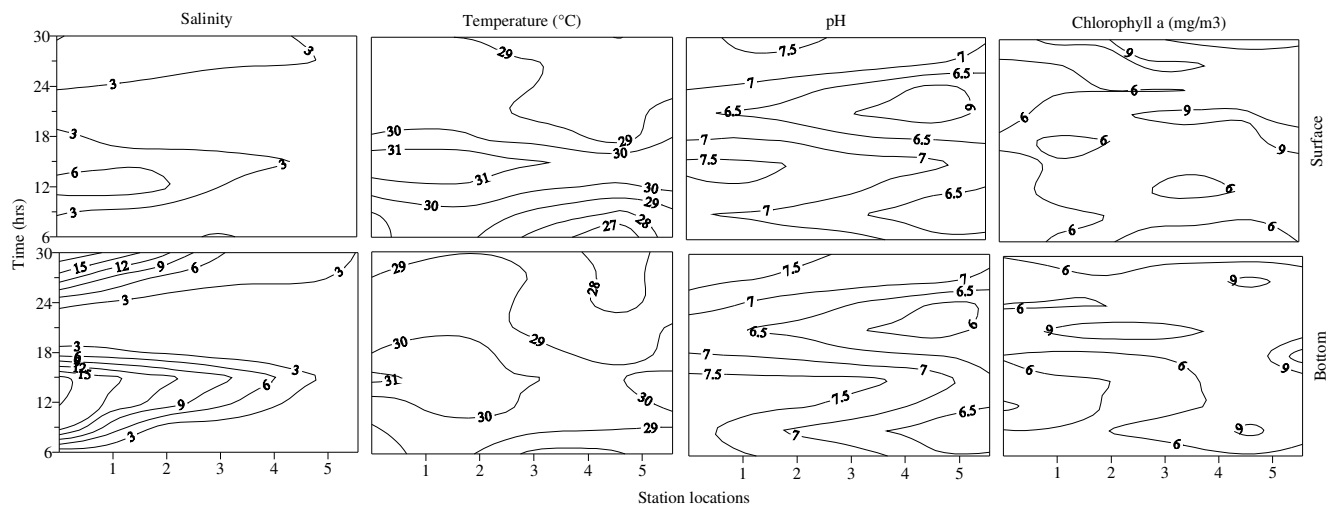

Figure 4. Time-series variation in salinity, temperature $\left({ }^{\circ} \mathrm{C}\right), \mathrm{pH}$ and chlorophyll $\left(\mathrm{mg} / \mathrm{m}^{3}\right)$ at surface and bottom waters on $28^{\text {th }}$ October 2003.
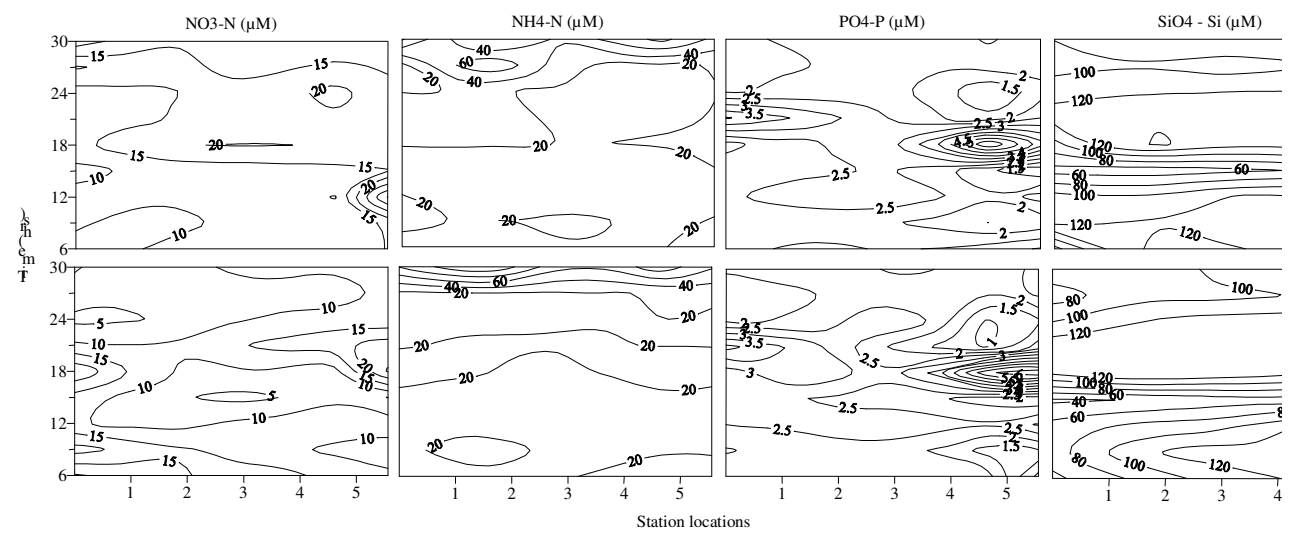

Figure 5. Time-series variations in nitrate $(\mu M)$, ammonia $(\mu M)$, phosphate $(\mu M)$ and silicate $(\mu M)$ at surface and bottom waters on $28^{\text {th }}$ October 2003. 


\section{Dissolved inorganic nutrients and chlorophyll a}

During March, the increased tidal activity ensured a vertical mixing, as evidenced by a uniform distribution of nutrients (Figure 2-5). Ammonium $\left(\mathrm{NH}_{4}{ }^{+}\right)$represented $80 \%$ of dissolved inorganic nitrogen (DIN), and its highest values were always associated with fresh water inflow. Phosphate was moderately high $(1.5-4.5 \mu \mathrm{M})$ in October, whereas the concentrations decreased towards upstream $(1.5 \mu \mathrm{M})$ in March. Fresh water flow enhanced the nitrate and silicate levels during the post monsoon $\left(\mathrm{NO}_{3} 10-30 \mu \mathrm{M}, \mathrm{SiO}_{4}\right.$ 60-130 $\mu \mathrm{M}$, Figure 5) indicating their upstream origin. Chlorophyll $a$ concentrations were low during October, possibly due to the reduced light intensity and swift currents, which probably exported the productive estuarine waters to the sea [20]. The chlorophyll $a$, which was low during October $\left(<10 \mathrm{mg} / \mathrm{m}^{3}\right)$, increased during March, especially towards upstream $\left(>45 \mathrm{mg} / \mathrm{m}^{3}\right)$. Another important observation was that, even with low transparency of the water column, the chlorophyll concentrations at sub surface $(2 \mathrm{~m})$ were fairly close to that in the surface waters on both occasions. Increased residence time of the estuary is probably resulting in an enhanced productivity in the Cochin backwaters during March [6].

Dissolved inorganic nutrients generally showed an inverse relationship with salinity, where the highest concentrations were recorded during the periods of lowest salinity (Figure 6, 7). Significant positive relationship $(\mathrm{n}=90)$ was found between salinity and $\mathrm{pH}\left(\mathrm{P}>0.01, r^{2}=0.51\right)$ during October, whereas it was low during March $\left(r^{2}=0.40\right)$. Nitrate and phosphate showed insignificant and inverse correlation with salinity $\left(r^{2}=\right.$ $0.03,02)$ during March and October $\left(r^{2}=0.08,02\right)$ respectively. Because of the extraneous input of ammonium compounds, the N/P ratio was high during March (60) as compared to October $(<20)$.
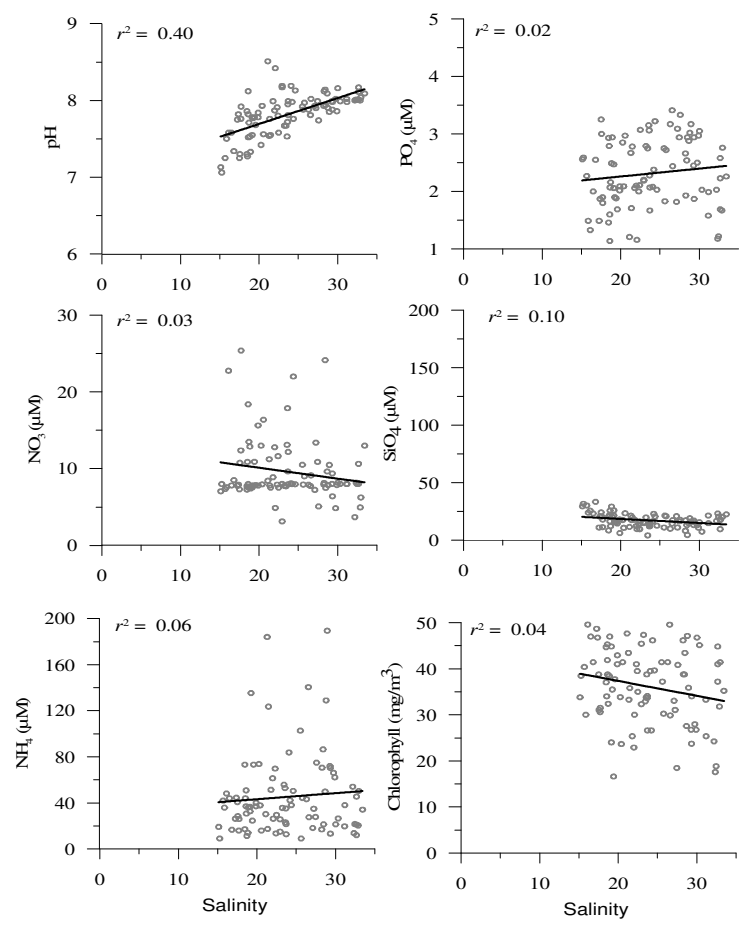

Figure 6. Scatter plots showing the linear correlation between salinity and different parameters in the study region during March $2004(n=90)$. 

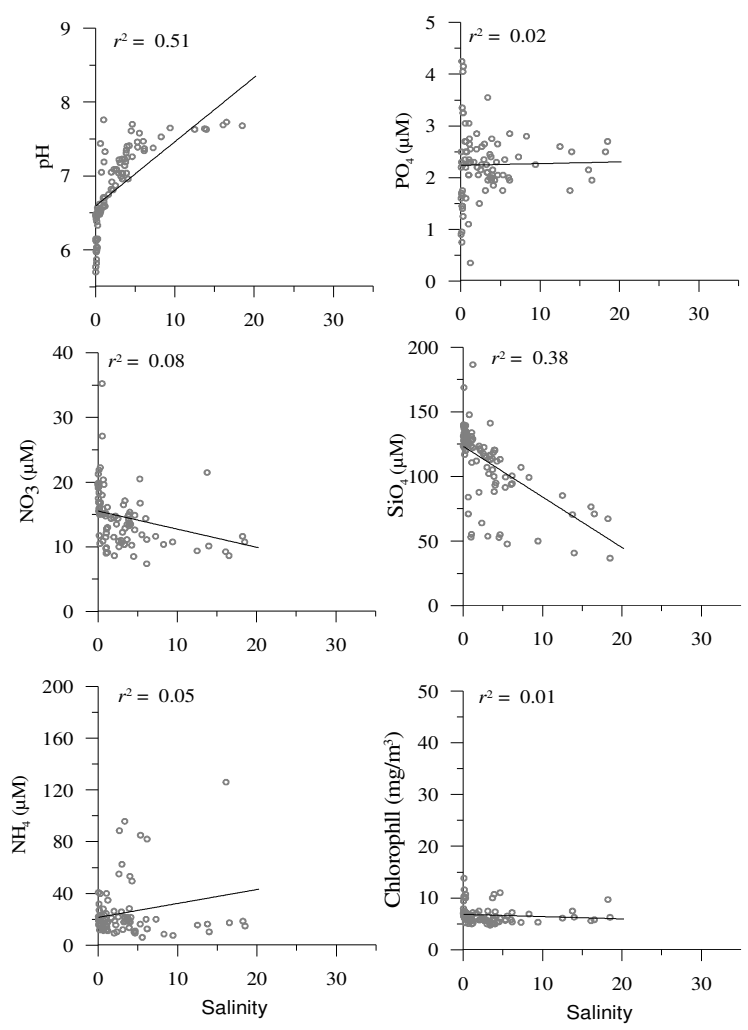

Figure 7. Scatter plots showing linear correlation between salinity and different parameters in the study region during October $2003(n=90)$.

Silicate was high only during October which showed negative correlation with salinity $\left(r^{2}=0.38\right)$. The generally vide scatter observed in the distribution of nutrients against salinity could be due to their excess loading into the region. The nutrients in general, maintained higher levels during March, but ammonia was high during October. Correlation between salinity and chlorophyll $a$ was also insignificant on both occasions $\left(\mathrm{r}^{2}<0.04\right)$ indicating that phytoplankton production in the estuary is not limited by these nutrients during all seasons.

\section{Discussion}

It is evident that high saline waters in the Cochin backwaters during March are supporting enhanced organic production. The river discharge is considerably reduced ( 2 $\%$ ) during this period, whereas during October, the region receives approximately $12 \%$ of the annual discharge [10]. During October, high $\mathrm{P}$ loading was observed from upstream. But pre monsoon season promoted an increased re-suspension in the water column, which released the adsorbed $P$ at higher salinities in the lower estuary [7, 9]. As a consequence, N/P ratio, which was $>80$ during October, was lowered to $<30$ during pre monsoon season. From the sediment trap experiments conducted during the same periods, it was observed that removal of $\mathrm{P}$ on to suspended matter during high river flow periods and their subsequent release to water column during lean river flow periods under high saline conditions are the characteristics of the phosphorus dynamics in the Cochin backwaters. The N/P ratio during post monsoon season was close to the 
Redfield ratio (16:1), mainly caused by a proportional increase in the phosphate input. With a considerable reduction in the fresh water flow from October to March and without much change in the nutrient input, the system was seen to transform into vertically mixed and eutrophic [6]. The enhancement of nutrients favoured high primary production owing to the prevalent solar insolation and sluggish movement of the estuarine waters [3].

\section{Conclusion}

The present dataset documents that anthropogenic activities are increasing nutrient loads to the backwaters in regions of escalated population growth, leading to many associated changes in environmental quality. This implies that changes in the hydrology induced by monsoon play an important role in regulating the nutrients, secondary production and even the migrant fauna of the estuary. The elevated inorganic and likely organic nutrient loadings are moving into and changing the pelagic food web. The significant variation in nutrients and their stoichiometric ratio; especially during post monsoon season is definitely a cause of concern regarding the health of the estuary. Trend analysis has shown that continuous release of nutrients and other pollutants into this estuary has not only inhibited the survival of higher predators including fishes, but also supported the proliferation of pollution tolerant species [2].

The hydrodynamically complex nature of the backwater system with increased renewal times as well as pollutant trapping efficiency, makes Cochin backwaters a delicately poised sensitive ecosystem. The region is undergoing an explosive development including an exclusive economic zone, container terminal, LNG terminal, single buoy mooring platform, international transshipment base, marina to attract tourists etc. In view of the alarming rate at which the population in this region is growing $\left(0.6 \times 10^{6}\right.$ in 1975 to $3 \times 10^{6}$ in 2002 and an expected $5 \times 10^{6}$ by 2025), there should be proper environmental conservation plans to minimize the excessive pollution, keeping pace with developmental impacts that are inevitable [2]. The most important control measures that should be prioritized are the indiscriminate reclamation of this wetland leading to its reduced flushing quality and, discharge of pre-treated industrial and domestic sewage causing eutrophication in water and contamination in sediments. The sampling program described here is to be continued to provide a useful field test of the functional relationships between nutrient loading, productivity and composition of pelagic ecosystem.

Acknowledgement. The authors wish to thank Dr. S.R. Shetye, Director, National Institute of Oceanography, Sh. Rasik Ravindra, Director, National Centre for Antarctic and Ocean Research,Goa, Dr.C.T.Achuthankutty, Scientist-in-Charge, NIO, Cochin and Dr.B.R.Subramanian, Director, ICMAMPD, Chennai for the encouragement and help. This study forms a part of the project "Ecosystem modeling of Cochin backwaters" funded by Integrated Coastal and Marine Area Management (ICMAM-PD), Ministry of Earth Sciences, Chennai.

\section{REFERENCES}

[1] Aston, S. R. (1980): Nutrients, dissolved gases and general bio-geochemistry of estuaries. - In: Chemistry and biogeochemistry of estuaries, edited by Olausson, E. and Cato, I. John., Wiley and Sons Ltd. 233-257. 
[2] Balachandran, K.K., Laluraj, C.M., M. Nair.,T. Joseph., P. Sheeba, P. Venugopal. (2005): Heavy metal Accumulation in a flow restricted, tropical estuary. - Est. Coast. Shelf Sci. 65:361-370.

[3] De Souza, S.N., Sen Gupta, R., Sanzgiri, S., Rajagopal, M.D. (1981): Studies on nutrients of Mandovi and Zuari river systems. - Indian J. Mar. Sci. 10: 314-321.

[4] Grasshoff, K. (1983): Methods of sea water analysis. - In: K. Grasshoff, M. Ehrhardt, K. Kremling (eds) $-2^{\text {nd }}$ Edn, Verlag Chemie, Weinheim. pp. 419.

[5] Laluraj, C.M., Kesavadas, V., Balachandran, K.K., Vijay John Gerson., Martin G.D., Revichandran, C., T. Joseph, M.Nair. (2006): Recovery of an estuarine system from tsunami impacts - southwest coast of India. - Environ. monitoring \& assessment. DOI.10.1007/s10661-006-9237-2, 1-5.

[6] Menon, N. N., Balchand, A. N., Menon, N. R. (2000): Hydrobiology of the Cochin backwater system - a review. - Hydrobiologia 430: 149-183.

[7] Sankaranarayanan, V.N., S.U. Panampunnayil (1979): Studies on the organic carbon, nitrogen and phosphorus in the sediments of Cochin backwaters. - Indian J. Mar. Sci. 8: 27-30.

[8] Sarala Devi, K., P. Venugopal, K.N. Remani, S. Laliyha, R. V. Unnithan (1979): Hydrographic features and water quality of Cochin backwaters in relation to industrial pollution. - Indian J. Mar. Sci. 8: 141-145.

[9] Sarala Devi, K., Sankaranarayanan, V.N., Venugopal, P. (1991): Distribution of nutrients in Periyar river estuary. - Indian J. Mar. Sci. 20: 49-54.

[10] Srinivas, K., Revichandran, C,. Maheswaran, P.A., Mohamed Ashraf, T.T., Nuncio Murukesh. (2003): Propagation of tides in the Cochin estuarine system, southwest coast of India. - Indian J. Mar. Sci. 32(1): 14-24.

[11] Strickland, J.D.H \& Parsons, T.R. (1972): A practical hand book of sea water analysis. $2^{\text {nd }}$ Ed. Bull. Fish. Res. Board Can. 167, pp.10.

[12] CPCB (1996). Pollution potential of industries in coastal areas of India. - Coastal Pollution Control Series COPOCS/ 9/1995-96. Central Pollution Control Board Report.

[13] Gopalan, U.K., Vengayil, Doyil T., Udaya Varma, P, Krishnankutty, M. (1983): The shrinking backwaters of Kerala. - Journal of Marine Biological Association of India 25, 131-141.

[14] Balachandran, K.K. (2001): Chemical oceanographic studies of the coastal waters of Cochin. - Doctoral thesis, Cochin University of Science and Technology, Cochin, India.

[15] Mallik, T. K \& Suchindran, G.K. (1984): Some sedimentological aspects of Vembanad Lake, Kerala, west coast of India. - Indian J. Mar. Sci. 13:159-163.

[16] Nair, C.K., Balchand, A.N. (1993). Speciation of trace metals in sediments of a tropical estuary. - Environ. Geol. 21:96-102.

[17] Balachandran, K.K., Laluraj, C.M., Martin, G.D., Srinivas, K., Venugopal, P. (2006a): Environmental analysis of heavy metal deposition in a flow-restricted tropical estuary and its adjacent shelf. - Environmental Forensics 7:1-7, 2006. DOI: $10.1080 / 15275920600996339$.

[18] Sankaranarayanan, V.N., Varma, P.U., Balachandran, K.K., Pylee, A., Joseph, T. (1986): Estuarine characteristics of the lower reaches of the river Periyar (Cochin backwaters). Indian J. Mar. Sci. 15, 166-170.

[19] Balachandran, K.K., Reddy, G.S., Srinivas, K., Revichandran, C., Vijayan, P.R., Tony, J.T. (2006b): Simulation of tides and tidal currents in a flow-restricted ecosystem (Cochin Estuary), India: Environmental significance. - Continental Shelf Research (in press).

[20] Jyothibabu, R., Madhu, N.V., Jayalakshmi, K.V., Balachandran, K.K., Shiyas, C.A., Martin, G.D., Nair K.K.C. (2006): Impact of freshwater influx on microzooplankton mediated food web in a tropical estuary (Cochin backwaters e India). - Estuarine, Coastal and Shelf Science 69, 505-518. 